\title{
Targeting HIV-1 envelope glycoprotein trimers to B cells using APRIL improves antibody responses
}

\author{
M Melchers, I Bontjer, T Tong, N Chung, P Klasse, D Eggink, M Gentile, A Cerutti, D Montefiori, W Olson, \\ B Berkhout, J Binley, J Moore, R Sanders
}

From AIDS Vaccine 2012

Boston, MA, USA. 9-12 September 2012

\section{Background}

An HIV-1 vaccine remains elusive, in part because various factors limit the quantity and quality of the antibodies raised against the viral envelope glycoprotein complex (Env). We hypothesized that targeting Env vaccines directly to $\mathrm{B}$ cells, by fusing them to molecules that bind and activate these cells, would improve Envspecific antibody responses.

\section{Methods}

We fused trimeric Env gp140 to A PRoliferation-Inducing Ligand (APRIL), B-cell Activating Factor (BAFF), and CD40 Ligand (CD40L).

\section{Results}

The Env-APRIL, Env-BAFF and Env-CD40L gp140 trimers all enhanced the expression of activation-induced cytidine deaminase (AID) expression, the enzyme responsible for inducing somatic hypermutation, antibody affinity maturation and antibody class-switching. They also triggered IgM, IgG and IgA secretion from human B cells in vitro. The Env-APRIL trimers induced higher anti-Env antibody responses in rabbits, including neutralizing antibodies against Tier 1 viruses. The enhanced Env-specific responses were not associated with a general increase in total plasma antibody concentrations, indicating that the effect of APRIL was Env-specific. All the rabbit sera raised against gp140 trimers, irrespective of the presence of CD40L, BAFF or APRIL, recognized trimeric Env efficiently, while sera raised against gp120 monomers did not. The levels of trimer-binding and virus-neutralizing antibodies were strongly correlated, suggesting that gp 140 trimers are superior immunogens to gp120 monomers.

Weill Medical College of Cornell University, New York, NY, USA

\section{Conclusion}

Targeting and activating B cells with a trimeric HIV-1 Env-APRIL fusion protein may improve the induction of humoral immunity against HIV-1. Targeting B cells directly may also be useful for other vaccines.

Published: 13 September 2012

doi:10.1186/1742-4690-9-S2-P300

Cite this article as: Melchers et al:: Targeting HIV-1 envelope

glycoprotein trimers to B cells using APRIL improves antibody

responses. Retrovirology 2012 9(Suppl 2):P300.
Submit your next manuscript to BioMed Central and take full advantage of:

- Convenient online submission

- Thorough peer review

- No space constraints or color figure charges

- Immediate publication on acceptance

- Inclusion in PubMed, CAS, Scopus and Google Scholar

- Research which is freely available for redistribution
() Biomed Central 